\title{
Early age behaviour of concrete supercontainers for radioactive waste disposal
}

\author{
Bart Craeye ${ }^{\mathrm{a}, *}$, Geert De Schutter ${ }^{\mathrm{a}}$, Hughes Van Humbeeck ${ }^{\mathrm{b}}$, Alain Van Cotthem ${ }^{\mathrm{c}}$ \\ a Magnel Laboratory for Concrete Research, Ghent University, Technologiepark-Zwijnaarde 904, 9052 Ghent, Belgium \\ b ONDRAF/NIRAS, Belgian Agency for Radioactive Waste and Enriched Fissile Materials, Belgium \\ c Tractebel Development Engineering, Consulting Company, Belgium
}

\section{A R T I C L E I N F O}

\section{Article history:}

Received 22 April 2008

Received in revised form 6 October 2008

Accepted 8 October 2008

Available online xxx

\begin{abstract}
A B S T R A C T
Various types of radioactive waste were and are produced in Belgium. This waste originates from different producers: nuclear power plants, medical applications, industry, research centre, etc. During the past 25 years several preliminary repository designs were proposed. Today, the cylindrical supercontainer is considered to be the most promising Belgian design on the matter of enclosing the vitrified high level radioactive waste (HLW) and the spent fuel assemblies and is based on the use of an integrated waste package composed of a carbon steel overpack surrounded by an Ordinary Portland Cement buffer. For the choice of this cementious buffer two compositions, a self-compacting concrete (SCC) and a traditional vibrated concrete (TVC), are being considered, tested and compared by means of an intensive laboratory characterization program. Through-going cracks in the concrete buffer should, at all times, be avoided because they will considerably ease the transport mechanisms inside the supercontainer. Therefore, finite element simulations are performed, using a 2.5-D thermal and crack modelling program, to predict the mechanical and thermal behaviour of the concrete buffer at any time during hardening. Looking at the finite element simulation results of the first stage of manufacturing of the supercontainer (cast in one), and the emplacement of the heat-emitting waste canister (second stage), we experience no early age cracking of the concrete buffer. The impact of environmental conditions and shrinkage and creep behaviour on the simulation results are noticeable.
\end{abstract}

(C) 2008 Elsevier B.V. All rights reserved.

\section{Introduction}

For the final disposal of long-lived, heat-emitting vitrified waste and spent fuel (category $C$ waste) in the deep Boom Clay layer, ONDRAF/NIRAS has developed a design, called supercontainer, based on the use of an integrated waste package composed of a carbon steel overpack surrounded by a concrete buffer based on Ordinary Portland Cement (Bel et al., 2005). The use of an outer stainless steel envelope, enclosing the concrete buffer, is being considered.

For the choice of the cementious buffer, a self-compacting and a traditional vibrated concrete will be tested and compared. The process of choosing a reference concrete composition for the buffer of the supercontainer is not straightforward, considering the requirements related to the thermo-physical behaviour and the mechanical strength.

A concrete characterization program, based on intensive laboratory work and large scale testing, has been carried out to obtain thermo-physical and mechanical properties of the con-

\footnotetext{
* Corresponding author. Tel.: +32 926455 29; fax: +32 92645845 .

E-mail address: Bart.Craeye@UGent.be (B. Craeye).
}

crete. The obtained data are used in finite element simulations to study the behaviour of the concrete buffer during the first step of manufacturing of the supercontainer, e.g. the fabrication of the concrete buffer inside the steel envelope, and during the second stage of manufacturing, e.g. the insertion of the heat-emitting waste.

Through-going cracks in the concrete buffer should, at all times, be avoided for radioprotection reasons but also to prevent contact of the pore water at low $\mathrm{pH}$ with the overpack. Therefore, knowledge of the behaviour of early age concrete has become non-negligible. Time-dependent deformations inside the concrete, such as shrinkage, creep and thermal deformation due to the heat of hydration, strongly affect the behaviour of young concrete that is just gaining resistance and stiffness. By adapting those parameters, we attempt to derive their influence on the hardening concrete.

\section{The supercontainer concept}

\subsection{Characterization of radioactive waste}

Various types of radioactive waste were and are produced in Belgium. This waste originates from different producers: nuclear power plants, medical applications, industry, research centre, 
Table 1

Different types of radioactive waste $(\mathrm{HL}=$ half-life $)$.

\begin{tabular}{llll}
\hline & Low level & Intermediate level & High level \\
\hline Short-lived $(\mathrm{SL}): \mathrm{HL}<30$ years & A & A & $\mathrm{C}$ \\
Long-lived $(\mathrm{LL}): \mathrm{HL}>30$ years & B & B & $\mathrm{C}$ \\
\hline
\end{tabular}

etc. Based on their activity and the half-life of the included radionuclides, the conditioned wastes are subdivided into three different categories: A, B and C (Table 1). The supercontainer is intended for the disposal of (vitrified) high level heat-emitting waste (Table 1 , category $C$ ) and for the disposal of spent fuel assemblies.

\subsection{Visualization of the supercontainer}

In this concept (Fig. 1b), the vitrified waste canisters or spent fuel assemblies are enclosed in a carbon steel overpack of about $30 \mathrm{~mm}$ thick. This overpack has to prevent contact of the waste with the water coming from the host formation during the thermal phase i.e. several 100's of years for vitrified waste and 1000's
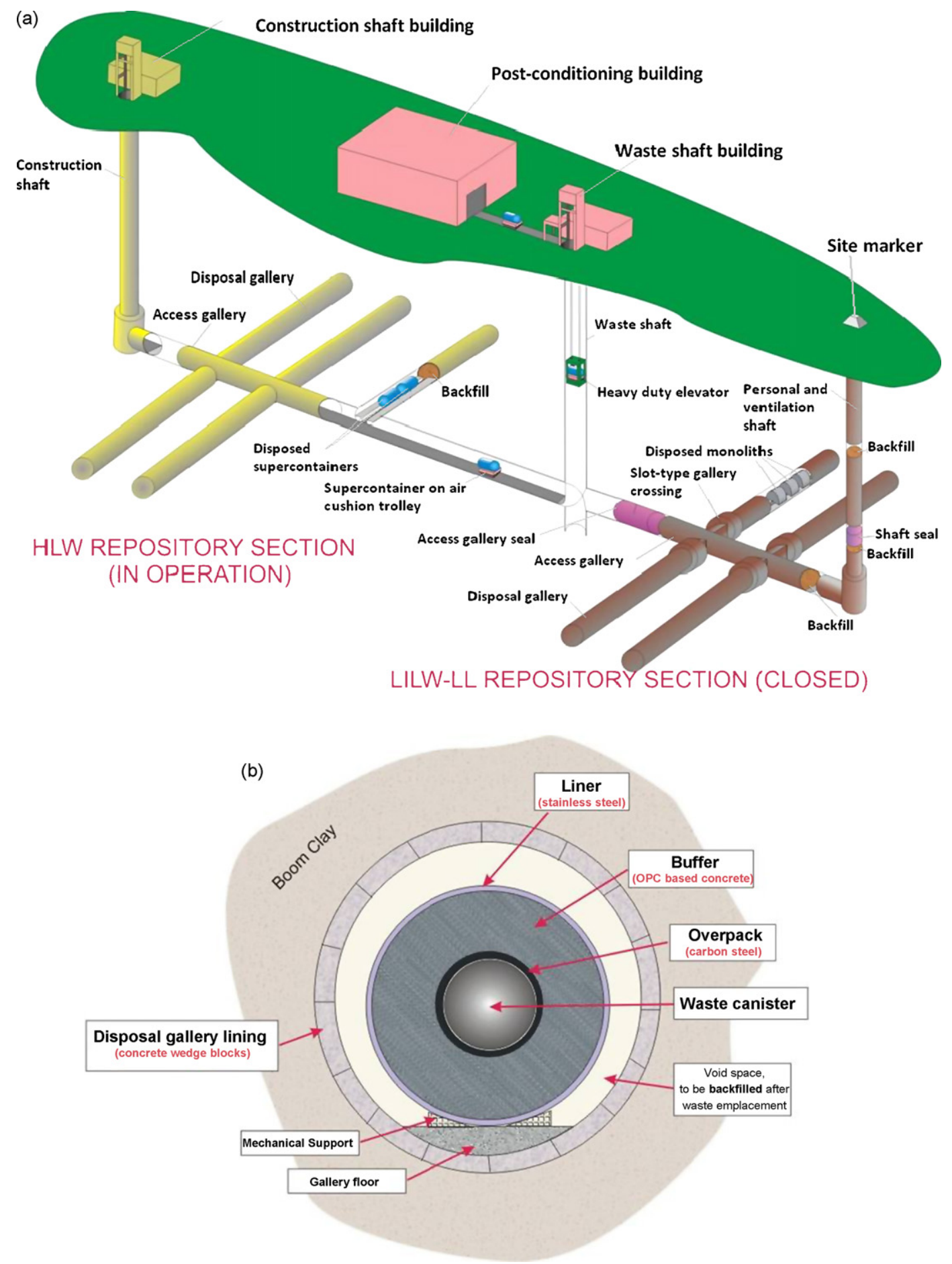

Fig. 1. (a) Artistic view of the disposal gallery. (b) Cross-section in a disposal gallery for vitrified HLW. 


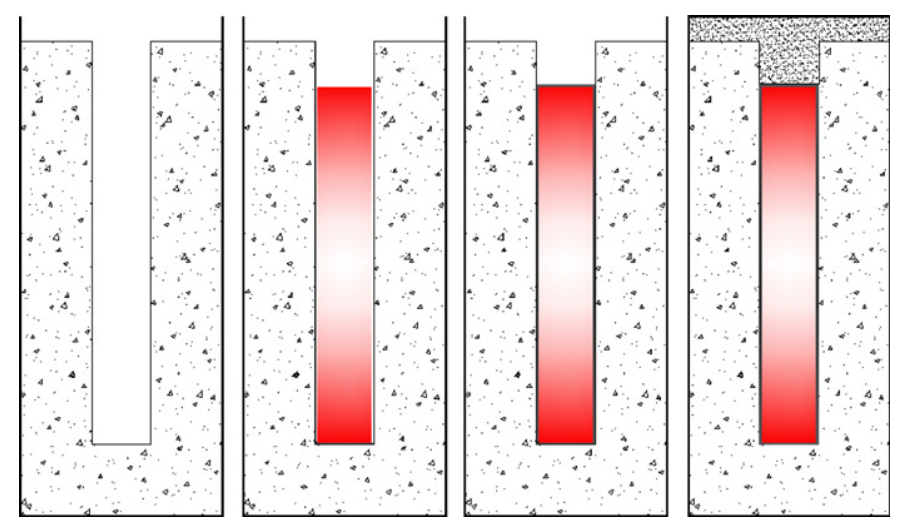

Fig. 2. Four construction steps of the supercontainer (steps 2-4 are carried out in hot cell).

of years for the spent fuel assemblies (ONDRAF/NIRAS, 2004). For corrosion protection purposes, the overpack is enveloped by a high $\mathrm{pH}$ concrete buffer (high alkaline concrete) (CUR, 2004). This buffer, with a thickness of about $70 \mathrm{~cm}$, also performs as a well-defined radiological protection buffer for the workers and simplifies underground waste transportation operations. This buffer probably will be surrounded by a stainless steel cylindrical envelope (also called liner) (Craeye et al., 2007). Once closed, the supercontainer will be transported to the repository (Fig. 1a) using an air cushion system and placed in a disposal gallery. The space between the supercontainer and the gallery lining is backfilled with grout (Fig. 1b). The outside radius of the supercontainer for vitrified waste is about $1.9 \mathrm{~m}$ and it has a total length of $4.2 \mathrm{~m}$ (about $6 \mathrm{~m}$ for spent fuel assembly).

\subsection{Different stages of manufacturing}

This study consists of an intensive laboratory characterization program and large scale testing. The obtained mechanical and thermo-physical data will be used in finite element simulations to study the behaviour of the concrete buffer during the different stages of manufacturing (Fig. 2):

1. Fabrication of the concrete buffer inside the steel envelope.

2. Emplacement, in hot cell, of the carbon steel overpack containing the waste canisters inside the concrete buffer.

3. Filling the remaining annular gap with a cementious grout (the filler) under thermal load.

4. Closing the supercontainer by fitting the concrete lid.

This article provides the calculations and simulations of the first two fabrication steps.

Through-going cracks in the concrete buffer should, at all times, be avoided for radioprotection reasons but also to prevent that pore water at low $\mathrm{pH}$ will contact the overpack.

Table 2

The concrete compositions of SCC and TVC.

\begin{tabular}{llc}
\hline Component & $\mathrm{SCC}\left(\mathrm{kg} / \mathrm{m}^{3}\right)$ & $\mathrm{TVC}\left(\mathrm{kg} / \mathrm{m}^{3}\right)$ \\
\hline Cement CEM I/42,5N HSR LA LH & 350 & 350 \\
Limestone filler & 100 & 50 \\
Limestone 0/4 & 840 & 708 \\
Limestone $2 / 6$ & 327 & 414 \\
Limestone 6/14 & 559 & 191 \\
Limestone 6/20 & 0 & 465 \\
Superplasticizer glenium 27/20 & 14.02 & 4.41 \\
Water & 175 & 175 \\
\hline
\end{tabular}

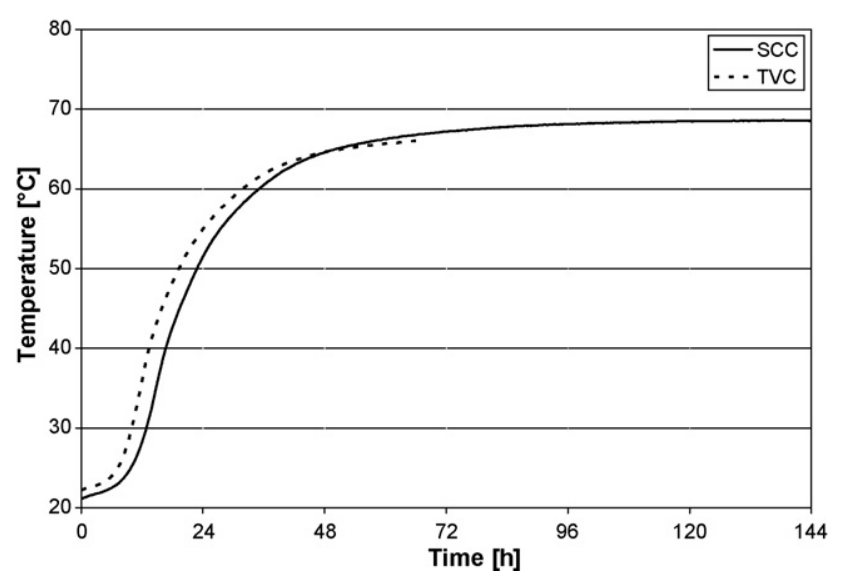

Fig. 3. Results of adiabatic hydration tests.

Table 3

Coefficient of thermal dilation for SCC and TVC.

\begin{tabular}{lllll}
\hline & Fresh & $8-24 \mathrm{~h}$ & $24-144 \mathrm{~h}$ & Hard \\
\hline SCC $\left({ }^{\circ} \mathrm{C}\right)$ & $14.5 \times 10^{-6}$ & $10.9 \times 10^{-6}$ & $8.7 \times 10^{-6}$ & $8.0 \times 10^{-6}$ \\
TVC $\left({ }^{\circ} \mathrm{C}\right)$ & $13.6 \times 10^{-6}$ & $10.2 \times 10^{-6}$ & $8.2 \times 10^{-6}$ & $7.5 \times 10^{-6}$ \\
\hline
\end{tabular}

\section{Early age behaviour of concrete}

The early age behaviour of massive concrete has become increasingly important. Massive hardening concrete elements are very

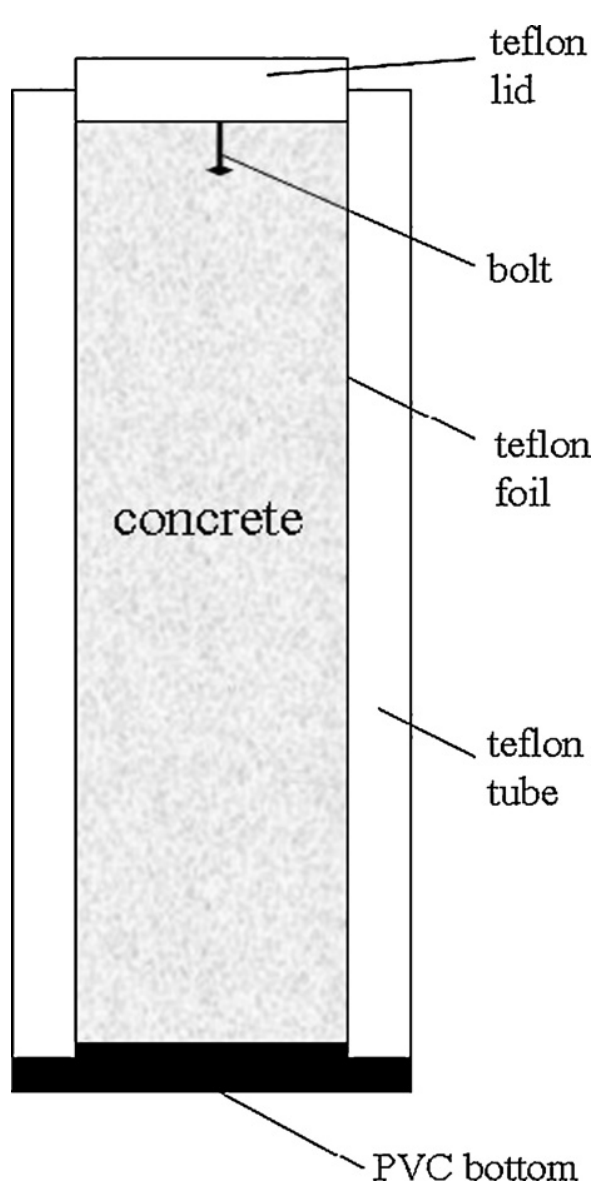

Fig. 4. Schematic view of vertical linear dilatometer for concrete. 


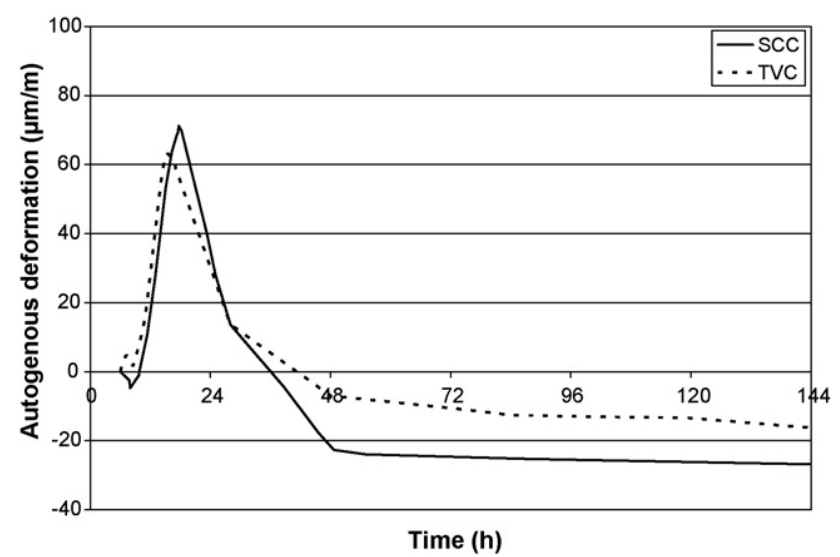

Fig. 5. The autogenous shrinkage at early age of SCC and TVC.

prone to early age thermal cracking due to the heat of hydration. The service life of the concrete element, can be severely reduced by the presence of even small thermal cracks (De Schutter, 2002). The main technological problem related to the production of the concrete buffer of the supercontainer, is the effect of the heat of hydration during hardening of the fresh concrete. On the other hand, the early age shrinkage, such as autogenous shrinkage, must also be taken into account. Finally creep, defined as the time-dependent increase of deformation under sustained load, affects bending of structure elements and stress distribution. All these effects should be taken into account in design, construction and maintenance of radioactive waste repositories.

Concrete is characterized by a low tensile strength. This is the main reason why cracks in concrete occur. Stresses that lead to cracks in concrete can be caused by different actions such as direct loading, prevented shrinkage and swelling, differential setting, etc. Especially young concrete is very sensitive to crack formation. In the transitional phase, meaning the phase where the fresh concrete develops into young hardening concrete, the concrete has a low tensile strength and limited deformation capacity. Meanwhile the cement inside the concrete produces an amount of hydration heat and expands in the middle. Cooling down of the concrete can create cracks. Another phenomenon is the evaporation of free water

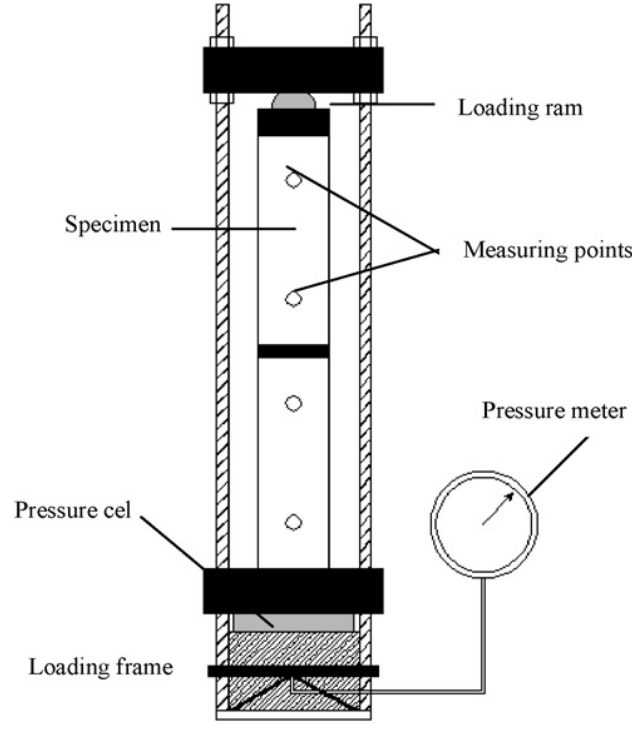

Fig. 7. Specimen setting for creep tests.

and bleeding water. If the amount of evaporated water exceeds the amount of bleeding water, capillary forces are induced. If the decrease of volume is prevented by the environment of the surface of a structure, tensile forces and cracks appear. Also autogenous shrinkage due to the self-desiccation of the fresh concrete can create cracks if the deformation is prevented. Finally, plastic setting of the aggregates in a very liquid concrete due to gravity can be counteracted by reinforcement or formwork. This also can lead to the formation of cracks.

The problem of early age cracking caused by the production of hydration heat and the development of autogenous shrinkage, occurring inside the concrete buffer, will be the main subject of the sequel of this paper. Simulations are performed using a powerful computer programme, yielding the evolving temperature fields and the resulting stresses at any time during hardening (Van Beek et al., 2001; De Schutter and Vuylsteke, 2004). The damage due to early age cracking is evaluated for the first stage of manufacturing of the supercontainer.

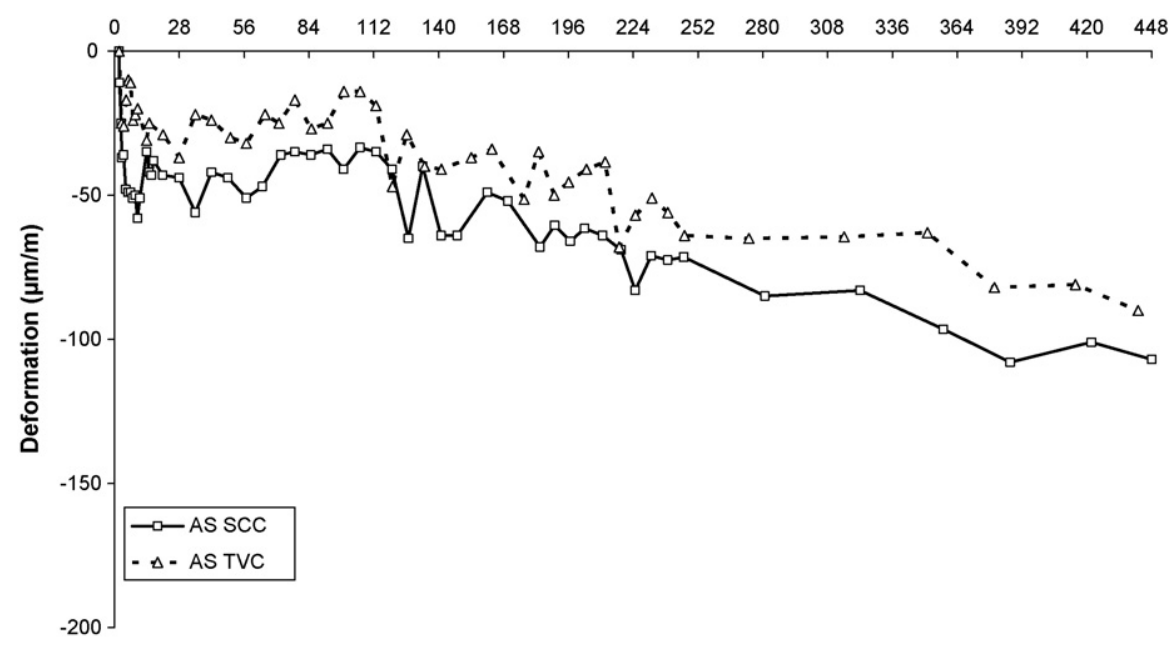

Age (days)

Fig. 6. The long term autogenous shrinkage of SCC and TVC. 


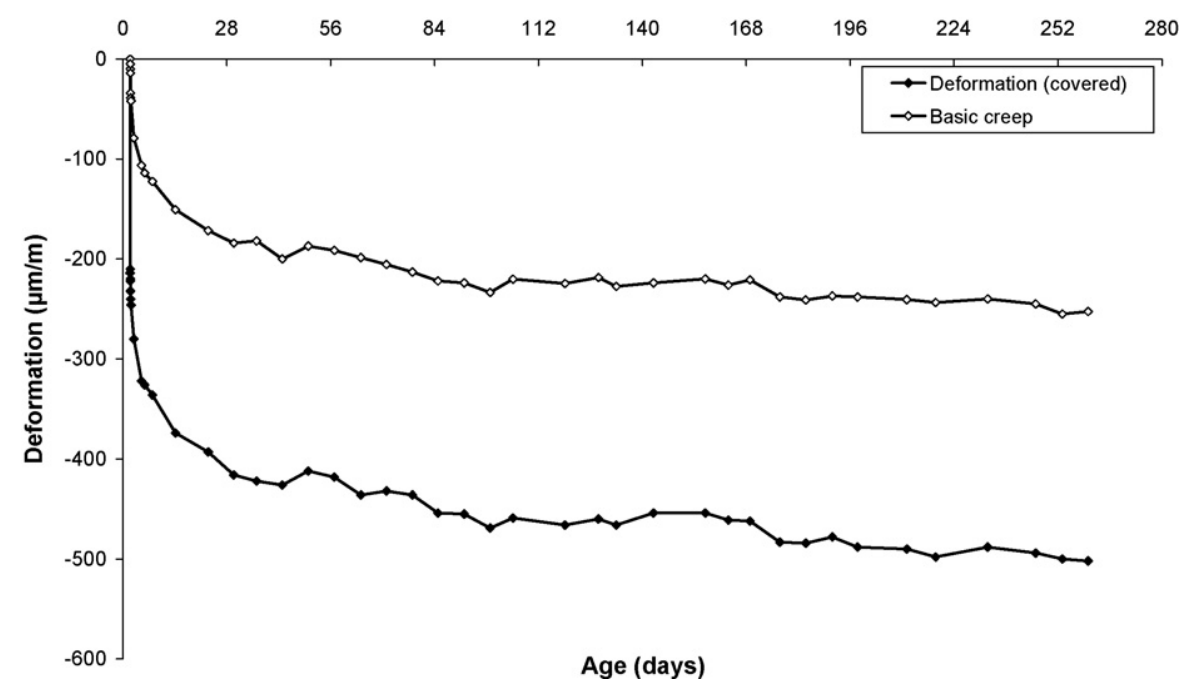

Fig. 8. Deformation and basic creep for SCC loaded after 2 days.

\section{The concrete buffer composition}

Two types of concrete are considered for the cementious buffer around the overpack: a self-compacting concrete (SCC)
(De Schutter et al., 2008) and a traditional vibrated concrete (TVC). Preference is given to the use of self-compacting concrete because it will ease considerably the precast process and complies with all other requirements regarding com-
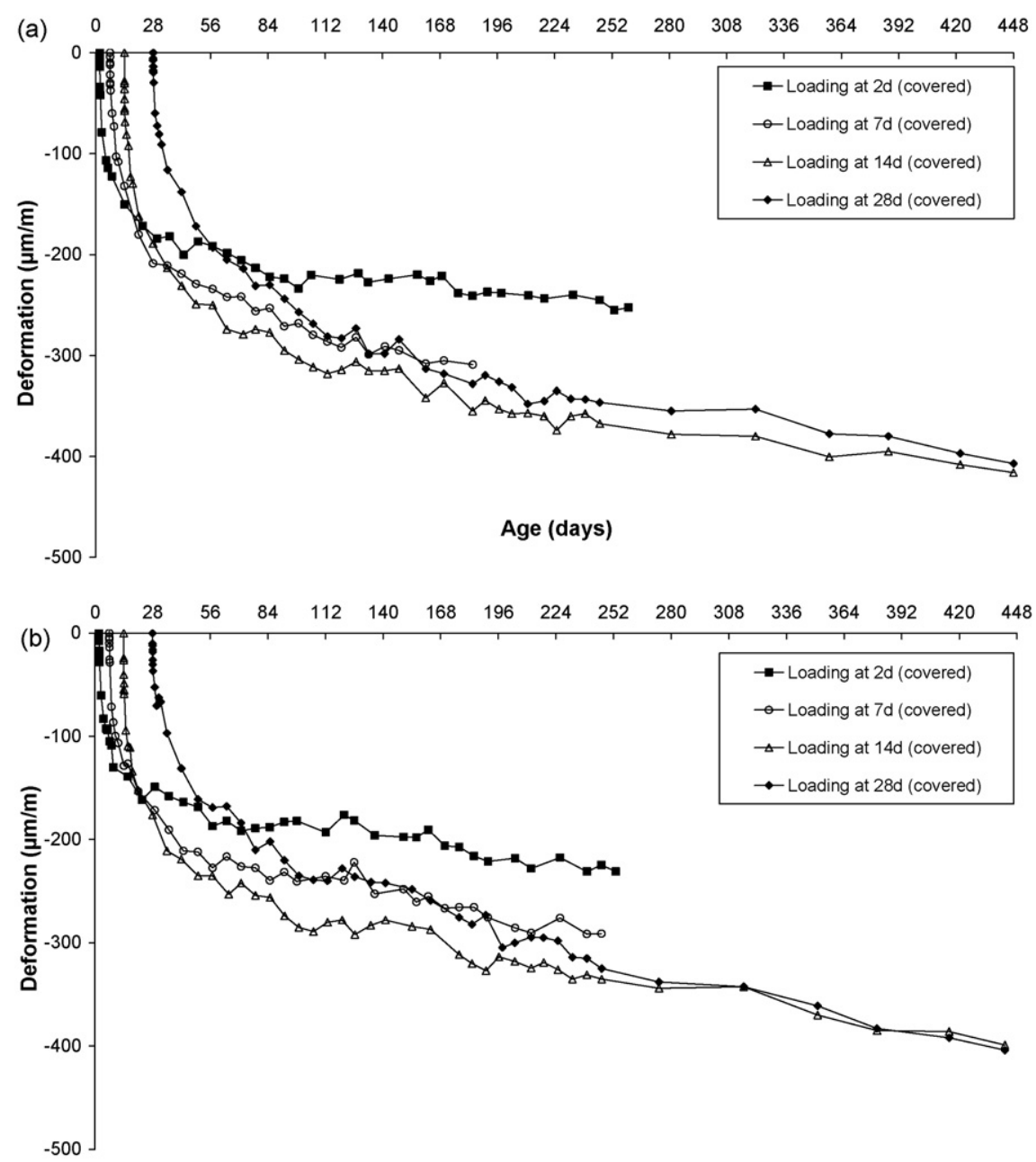

Age (days)

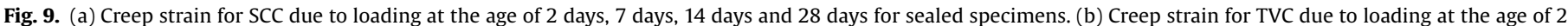
days, 7 days, 14 days and 28 days for sealed specimens.

Please cite this article in press as: Craeye, B., et al., Early age behaviour of concrete supercontainers for radioactive waste disposal. Nucl. Eng. Des. (2008), doi:10.1016/j.nucengdes.2008.10.006 


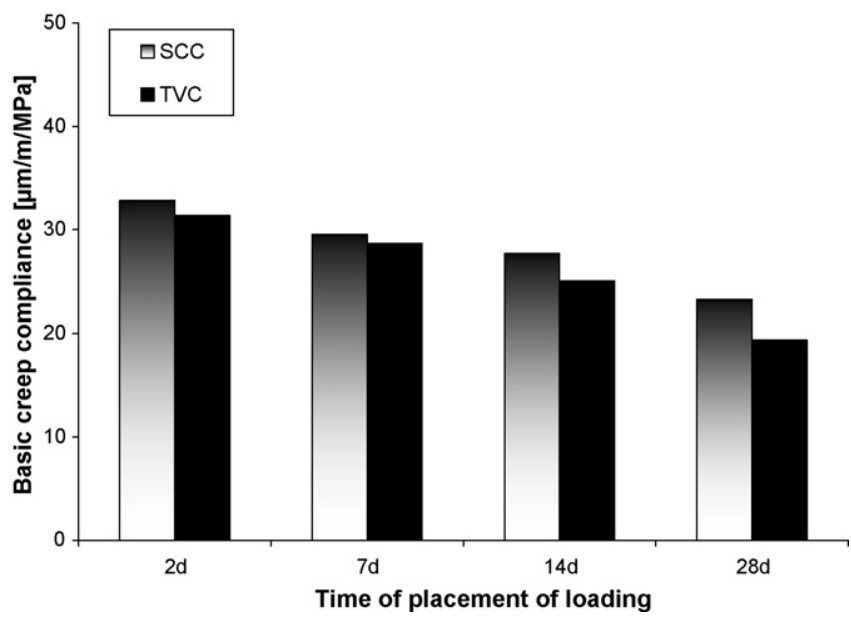

Fig. 10. Comparison of basic creep compliance of SCC and TVC after 168 days. pressive strength, long term durability, chemical interactions, etc.

There are certain restrictions to the different components of the buffer. It is recommended that CEM I, Portland Cement, with limited hydration heat production to avoid or limit thermal cracking, is used to prevent portlandite consumption (with additional $\mathrm{pH}$ drop), with additional restriction that the cement has a low $\mathrm{SO}_{3}$ and $\mathrm{C}_{3} \mathrm{~A}$ content. This avoids formation of dense hydrogarnet with resulting increase of porosity and permeability. The concrete must have high sulphate resistance to better resist to sulphur species present in Boom Clay pore water. It is also recommended that both fine and coarse aggregates should be limestone (calcium, calcite) containing not more than $2 \%$ each of magnesium, silicon and aluminium (as oxides). This limits the formation of $\mathrm{CSH}$ phases (alkali-aggregate reaction) resulting in expansion and cracking. No other organic additives are acceptable except, as low quantity as possible, a small amount of superplasticizer.

The concrete compositions further considered in this paper, are given in Table 2.
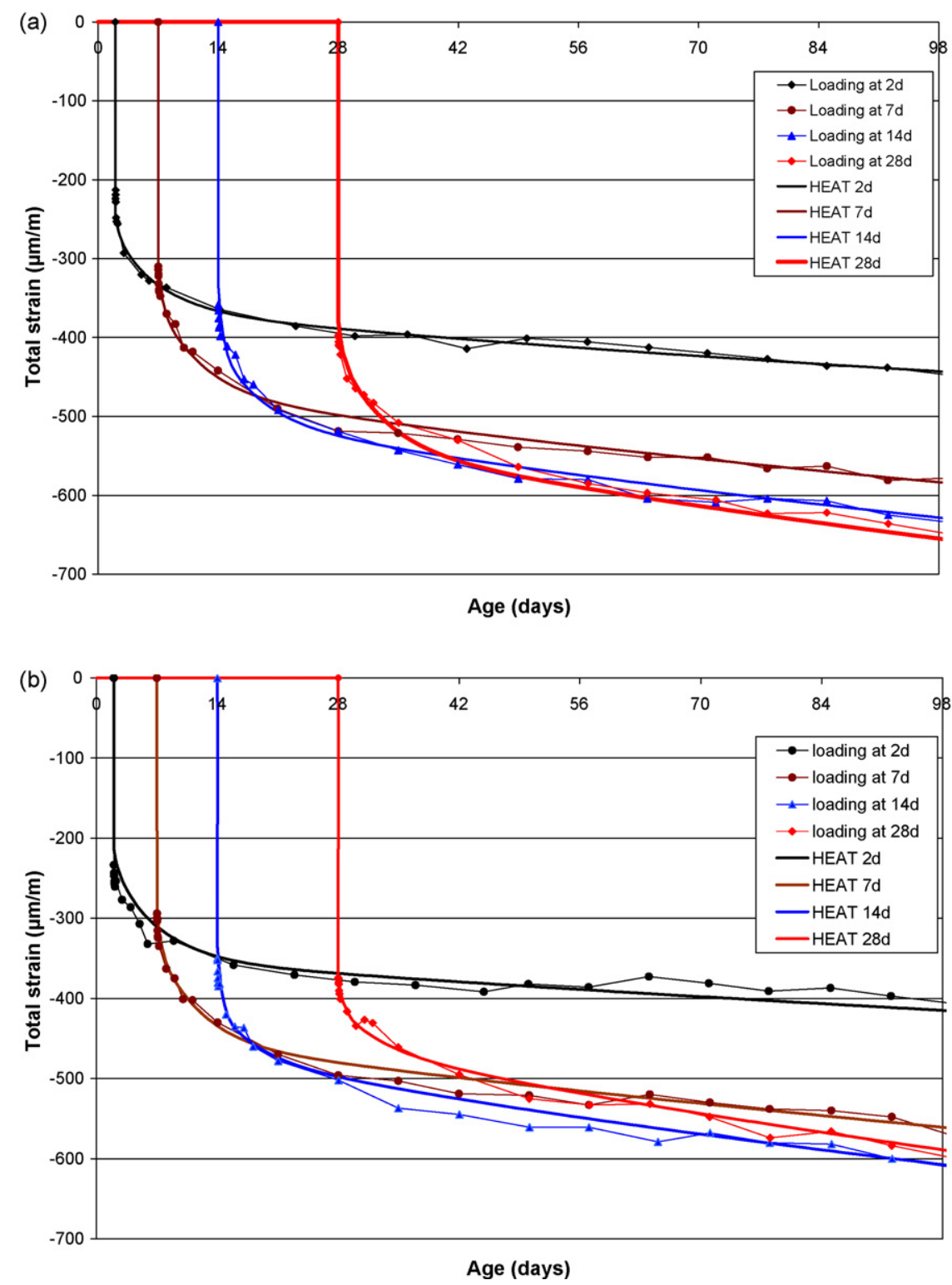

Fig. 11. (a) Maxwell fitting of the total strain of SCC. (b) Maxwell fitting of the total strain of TVC. 
Table 4

Values for compressive and tensile strength of SCC and TVC.

\begin{tabular}{|c|c|c|c|c|c|c|}
\hline \multirow[t]{2}{*}{ Age } & \multicolumn{3}{|l|}{ SCC } & \multicolumn{3}{|l|}{$\mathrm{RPC}$} \\
\hline & $f_{\mathrm{c}}(\mathrm{MPa})$ & $s$ & $f_{\text {ct }}(\mathrm{MPa})$ & $f_{\mathrm{c}}(\mathrm{MPa})$ & $\mathrm{s}$ & $f_{\mathrm{ct}}(\mathrm{MPa})$ \\
\hline 0 & 0 & 0 & 0 & 0 & 0 & 0 \\
\hline 1 & 13.7 & 2.5 & 1.6 & 15.4 & 3.1 & 1.6 \\
\hline 2 & 22.9 & 3.3 & 2.3 & 23.7 & 3.3 & 2.2 \\
\hline 3 & 28.7 & 5.1 & 2.6 & 28.7 & 3.7 & 2.5 \\
\hline 7 & 40.6 & 2.3 & 3.4 & 38.6 & 2.6 & 3.0 \\
\hline 14 & 49.3 & 2.8 & 3.8 & 45.5 & 1.5 & 3.4 \\
\hline 28 & 56.5 & 2.7 & 4.2 & 51.0 & 5.2 & 3.7 \\
\hline
\end{tabular}

\section{The concrete properties}

The determination of the concrete properties of SCC and TVC is part of an intensive laboratory characterization program. Several thermo-physical and mechanical tests are performed to predict the difference between these two compositions and will be implemented in the material database of the finite elements programme HEAT (Van Beek et al., 2001; De Schutter and Vuylsteke, 2004). This material database can be subdivided into three categories: thermal properties, maturity-related properties and mechanical properties.

\subsection{Thermal properties}

The specific heat of the SCC is fixed at $2420 \mathrm{~kJ} /\left(\mathrm{m}^{3} \mathrm{~K}\right)$ while the value for TVC is slightly higher, $2440 \mathrm{~kJ} /\left(\mathrm{m}^{3} \mathrm{~K}\right)$. Also the heat conduction coefficient is higher in case of TVC $(2.02 \mathrm{~W} /(\mathrm{m} \mathrm{K}))$ in comparison with SCC $(1.89 \mathrm{~W} /(\mathrm{m} \mathrm{K}))$. Although in reality these properties depend on the hydration process, only constant values are considered in HEAT. The heat production is simulated using the results of the adiabatic hydration tests according to De Schutter and Taerwe (1996). The results are shown in Fig. 3. The coefficient of thermal dilation (CTD) can be somewhat higher at very early age and therefore it is taken time dependent (Table 3).

\subsection{Maturity-related properties}

For the maturity concept, the reference temperature $T_{\text {ref }}=293 \mathrm{~K}$ $\left(20^{\circ} \mathrm{C}\right)$. The ratio $\mathrm{Q} / \mathrm{R}$ can be determined from the results of the isothermal hydration tests at different temperatures $\left(10^{\circ} \mathrm{C}, 20^{\circ} \mathrm{C}\right.$ and $35^{\circ} \mathrm{C}$ ) (Poppe and De Schutter, 2004). Q/R is equal to $4491 \mathrm{~K}$ for SCC and $4571 \mathrm{~K}$ for TVC.

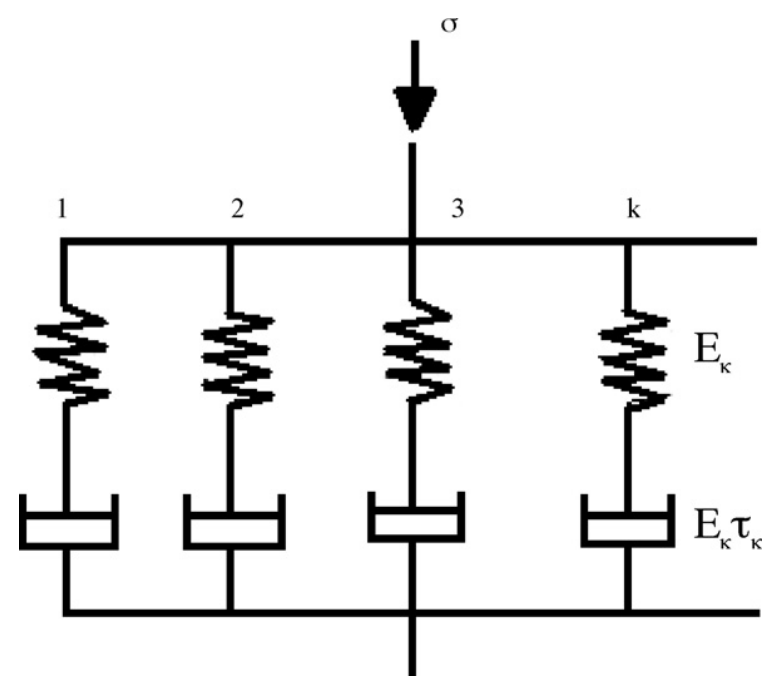

Fig. 12. Maxwell model for visco-elastic material behaviour of massive concrete.

\subsection{Mechanical properties}

The autogenous shrinkage at early age was determined according to Craeye and De Schutter (2006) (Fig. 5). At the Magnel Laboratory for Concrete Research, Ghent University, a vertical dilatometer for concrete has been developed (Fig. 4). Linear vertical shrinkage measurements can start immediately after casting, by means of LVDT-transducers. Temperature measurements are performed in parallel, in order to take into account the effect of the heat of hydration on the autogenous shrinkage results. The plotted values are obtained after removal of the thermal strains. Shrinkage is taken negative. The autogenous shrinkage, measured at $20^{\circ} \mathrm{C}$ on two specimens is shown in Fig. 5. The behaviour of SCC and TVC is quite similar: first a swelling occurs with a peak at approximately $16 \mathrm{~h}$ (TVC) and $18 \mathrm{~h}$ (SCC) after casting, followed by autogenous shrinkage development. An average autogenous shrinkage value of $-76 \mu \mathrm{m} / \mathrm{m}$ (TVC) and $-96 \mu \mathrm{m} / \mathrm{m}$ (SCC) is noticed after $144 \mathrm{~h}$, measured from the top of the swelling peak until the end of the test period $(144 \mathrm{~h})$.

To predict the long term shrinkage behaviour of the SCC and the TVC, additional tests were carried out according to the Belgian Code NBN B15-228. The shrinkage is determined on two covered prismatic test pieces (height $500 \mathrm{~mm}$, side $150 \mathrm{~mm}$ ) to determine the autogenous shrinkage (AS). Each test specimen has four measurement bases. The measurements are performed with a DEMEC-deformation gauge with an accuracy of $8 \times 10^{-6}$ and start after 2 days. Shrinkage is taken negative. The shrinkage development for TVC is slightly lower than for SCC (Fig. 6).

The creep of the concrete can be determined according to the Belgian Code NBN B15-228. First the total deformation is determined on two prismatic test pieces (one free specimen, one covered

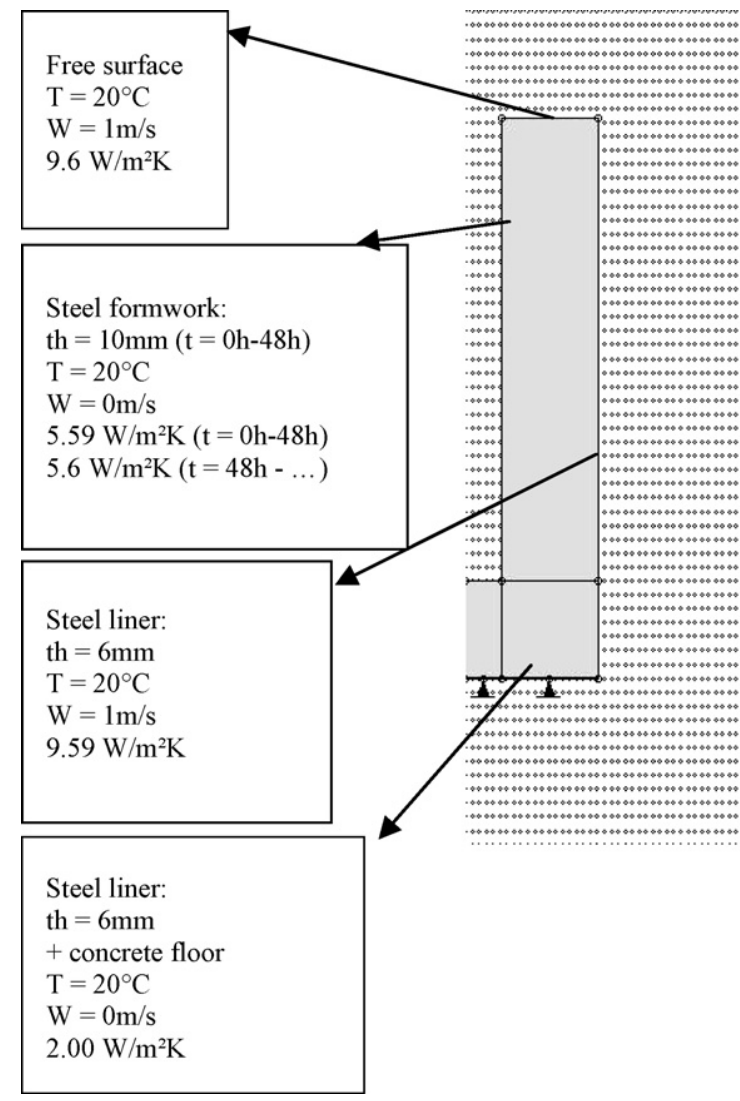

Fig. 13. The axisymmetrical model of the concrete buffer with the boundary conditions. 


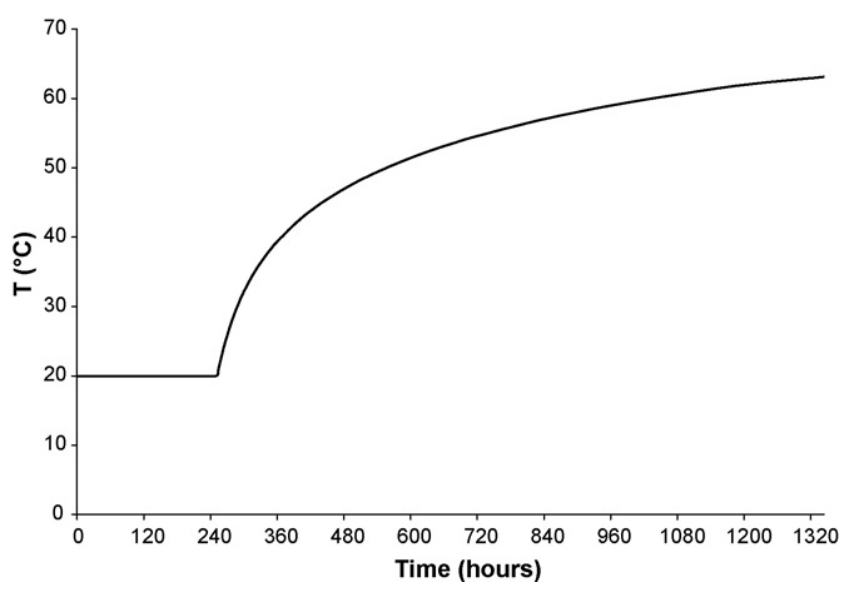

Fig. 14. Temperature development at the inner surface of the concrete buffer.

with aluminum foil) inside the creep apparatus (Fig. 7). We only look at the creep results of the covered pieces. A sealed specimen is used for the measurement of basic creep. By subtracting the instantaneous deformation (when the loading is placed on the test specimens) and the value of the autogenous shrinkage from the mean value of the total deformation, the basic creep value is obtained. Each test specimen has four measurement bases, one on each side. The measurements are performed with the same DEMECdeformation gauge.

At the age of 2 days, 7 days, 14 days and 28 days, the tests specimens are placed in the creep apparatus and loaded immediately. The experimental results of creep have been obtained under compression, supposing the creep is identical in compression and traction. The loading is $30 \%$ of the momentaneous strength of the test pieces $\left(0.3 f_{\mathrm{c}}\right)$. The total deformation is being measured during a long period of time. Shrinkage is taken negative.

It can be seen that, in case of SCC and TVC, the creep strains increase steeply up to 1 month, and than increase smoothly with age (Fig. 8). SCC has a higher creep development than TVC (Figs. 9 and 10). The tests are carried out in conditioned environment with an overall temperature of $20^{\circ} \mathrm{C}$ and a relative humidity of $60 \%$. Strains are measured immediately before and after loading, repeatedly the first $6 \mathrm{~h}$ after loading, then daily for a week and weekly afterwards.

From the comparison (Fig. 10), it is shown that SCC and TVC have the tendency to have larger basic creep compliance at younger ages. Also the basic creep is larger for SCC.

The Poisson's ratio is also taken time dependent. Its value is equal to 0.5 if the age of the concrete is below $7 \mathrm{~h}$ and is equal to 0.2 from $12 \mathrm{~h}$. It varies linear between those two values.

The strength development of the concrete is modelled according to Eq. (1a):

$f_{\mathrm{c}}(t)=f_{\mathrm{cm}}(28) \exp \left[s\left(1-\left(\frac{28}{t}\right)^{1 / 2}\right)\right]$

with $f_{\mathrm{c}}(t)$ the strength at time $t, f_{\mathrm{cm}}(28)$ the mean value of the strength at 28 days in ideal conditions, and $s$ a parameter depending on the cement type. Table 4 gives a summary of the obtained values for compressive and tensile strength.

The modulus of elasticity is determined out of nine cores taken out of an in situ casted column. At the time of testing, the concrete has an age of 28 days. The development of Young's modulus is modelled according to Eq. (1b):

$E_{\mathrm{c}}(t)=E_{\mathrm{cm}}(28) \exp \left[s\left(1-\left(\frac{28}{t}\right)^{1 / 2}\right)\right]$ with $E_{\mathrm{c}}(t)$ the modulus of elasticity at time $t, E_{\mathrm{cm}}(28)$ the mean value of the modulus at 28 days, and $s$ a parameter depending on the cement type. $E_{\mathrm{cm}}(28)$ equals $36.1 \mathrm{GPa}(s=2.8)$ for SCC and $32.4 \mathrm{GPa}$ $(s=2.1)$ for TVC.

The visco-elastic behaviour is modelled by mean of a Maxwell Chain Fitting approach (Fig. 11a and b, ). The chain parameters are determined by means of the above mentioned creep test results. It's the total strain that concerns us, and this total strain is found by subtracting the shrinkage of a covered specimen from the total deformation of a covered specimen at any given time:

$\varepsilon_{\text {tot str, } i}=\varepsilon_{\text {tot } c o v, i}-\varepsilon_{\text {shr cov }, i}$

The drying shrinkage and the moisture transport are kept out of consideration in these simulations. It's mainly the heat transportation that is of our main interest.

Softening behaviour is not taken into account.

\section{The numerical simulation tool}

For the numerical simulation of the first stage of manufacturing of the supercontainer, the finite elements programme HEAT has been used. HEAT calculates the stresses (due to temperature and humidity effects) and the strength in the concrete structure using a state parameter approach linked by a material database. The information belonging to each material in this database is obtained with experiments. First, the actual state parameters are calculated (like degree of hydration or maturity, temperature), and afterwards, stress calculations are realized. The programme simulates the hydration process in the structure and calculates the stresses and strength in the concrete structures. Although the simulation tool is mainly two-dimensional, an accurate simulation
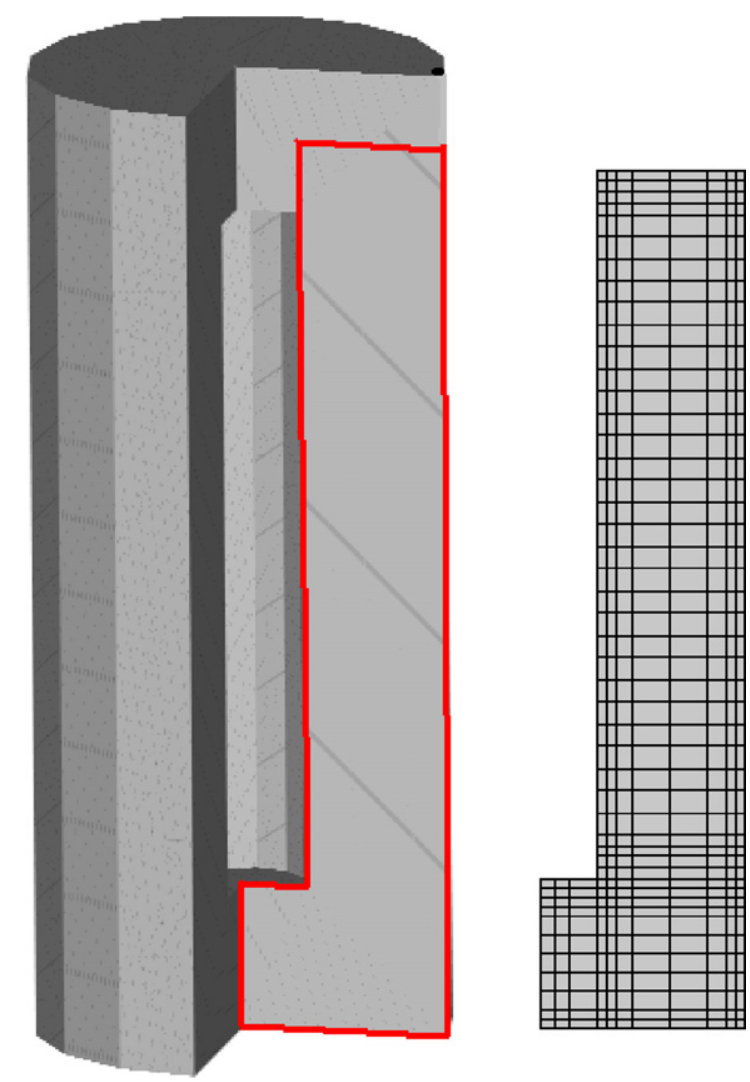

Fig. 15. The axisymmetrical cross-section of the supercontainer (left) and the finite element mesh (right). 

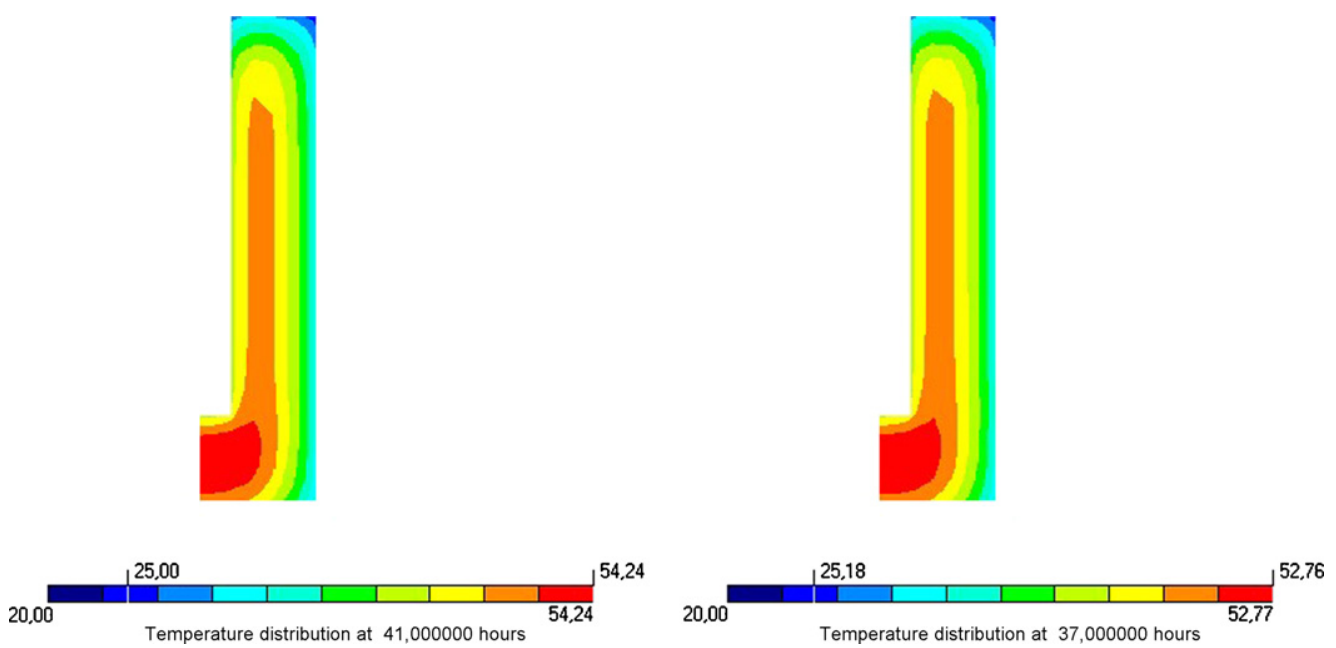

Fig. 16. Contourplot of the temperature after $41 \mathrm{~h}$ (left, SCC) and $37 \mathrm{~h}$ (right, TVC), casting temperature $20^{\circ} \mathrm{C}$, environmental temperature $20^{\circ} \mathrm{C}$.
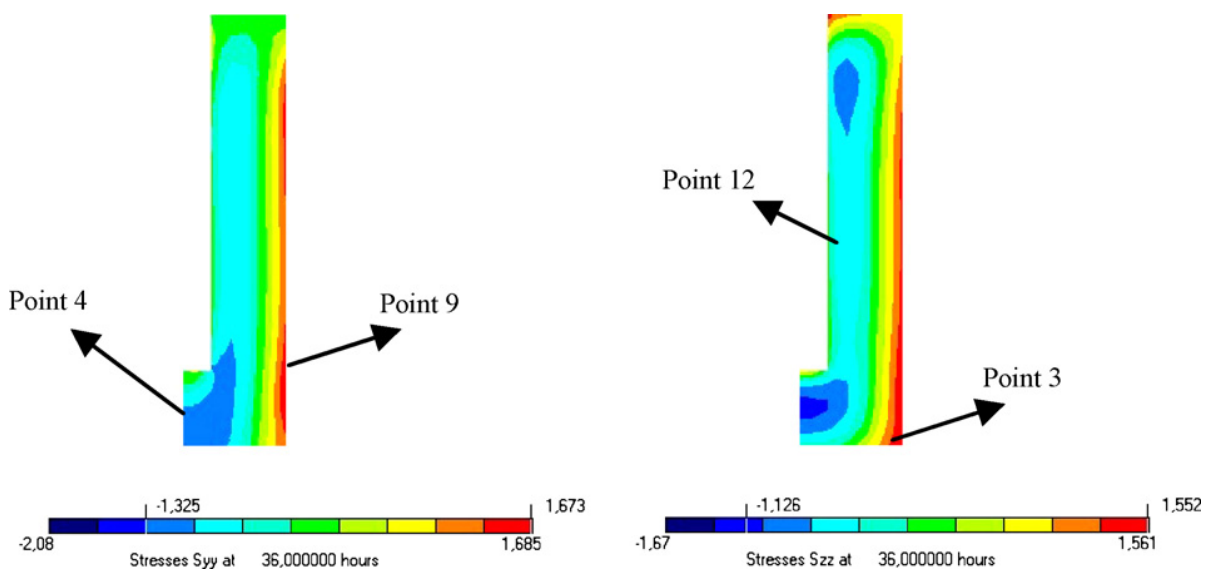

Fig. 17. Contourplot of $S_{y y}$ (left) after $36 \mathrm{~h}$ and $S_{z z}$ (right) after $36 \mathrm{~h}$, casting temperature $20^{\circ} \mathrm{C}$, environmental temperature $20^{\circ} \mathrm{C}$ (for SCC).

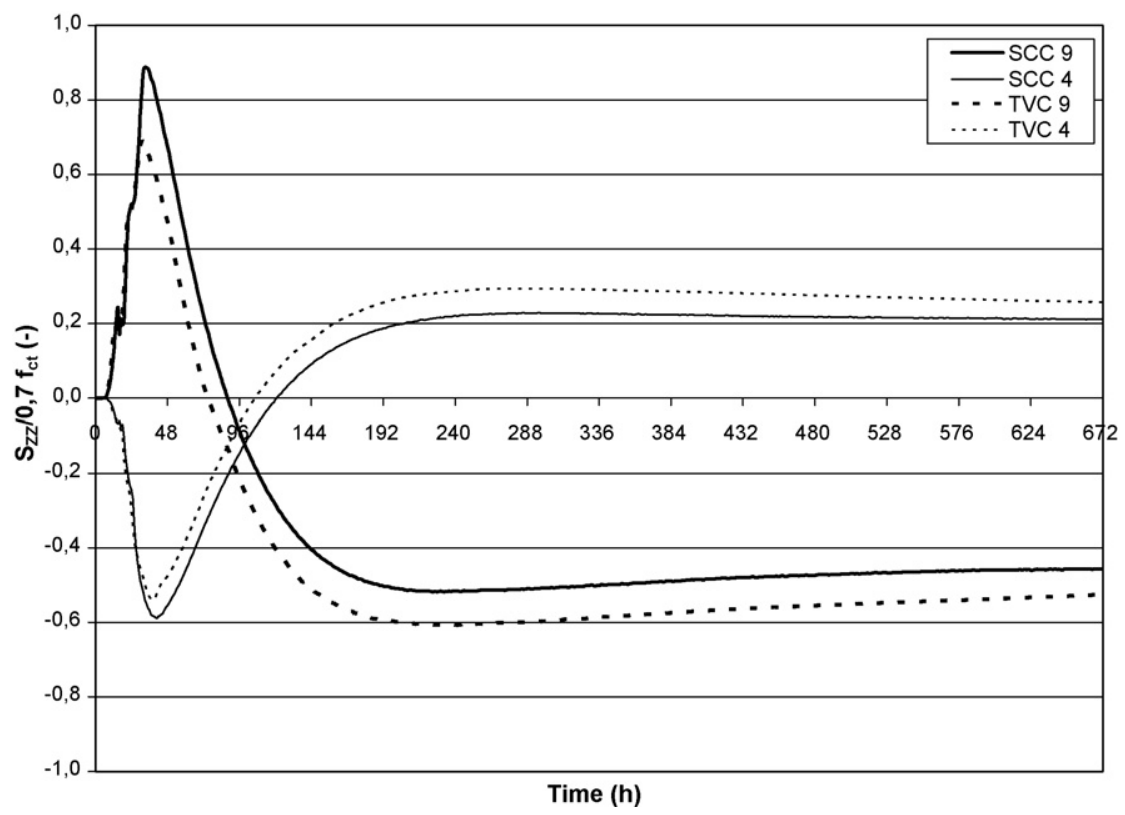

Fig. 18. Time graph of the stress-strength ratio $S_{z z} / 0.7 f_{\mathrm{ct}}$ for SCC and TVC at points 9 and 4 .

Please cite this article in press as: Craeye, B., et al., Early age behaviour of concrete supercontainers for radioactive waste disposal. Nucl. Eng. Des. (2008), doi:10.1016/j.nucengdes.2008.10.006 


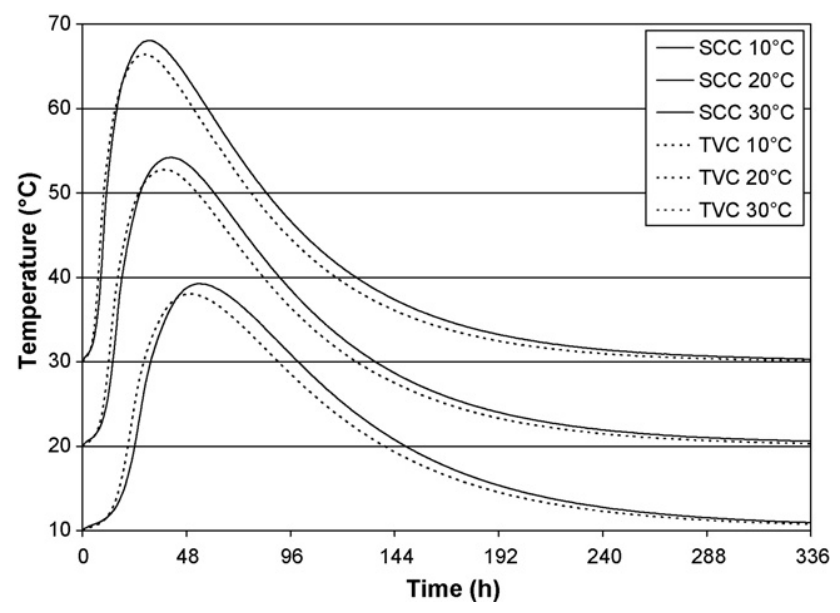

Fig. 19. Time graph of temperature development for SCC and TVC at point 4, casting temperature $10-20-30{ }^{\circ} \mathrm{C}$.

is possible in case of an axisymmetrical structure. In order to obtain a more realistic simulation, the use of a three-dimensional finite element method is inevitable but will be more cumbersome and time-consuming. The simulations of HEAT are based on a number of material models to calculate the effect of the environment on the material in a structure. The models that are of importance for the determination of cracks in young concrete are outlined.

The mathematical theory of heat transfer in isotropic media is based on Fick's first law, i.e. the rate of heat transfer through a unit area of a section is proportional to the temperature gradient normal to the section:

$\vec{q}=-\lambda_{\mathrm{T}} \nabla T$

with $q$ the heat flux, $\lambda_{\mathrm{T}}$ the thermal conductivity, and $T$ the temperature. The partial differential equation describing the heat transfer under transient conditions is given by Fick's second law:

$c_{\mathrm{T}} \frac{\partial T}{\partial t}=\frac{\partial}{\partial x}\left(\lambda_{\mathrm{T}} \frac{\partial T}{\partial x}\right)+\frac{\partial}{\partial y}\left(\lambda_{\mathrm{T}} \frac{\partial T}{\partial y}\right)+H_{\mathrm{t}}$

$c_{\mathrm{T}}$ is the heat capacity and $H_{\mathrm{t}}$ a heat source.

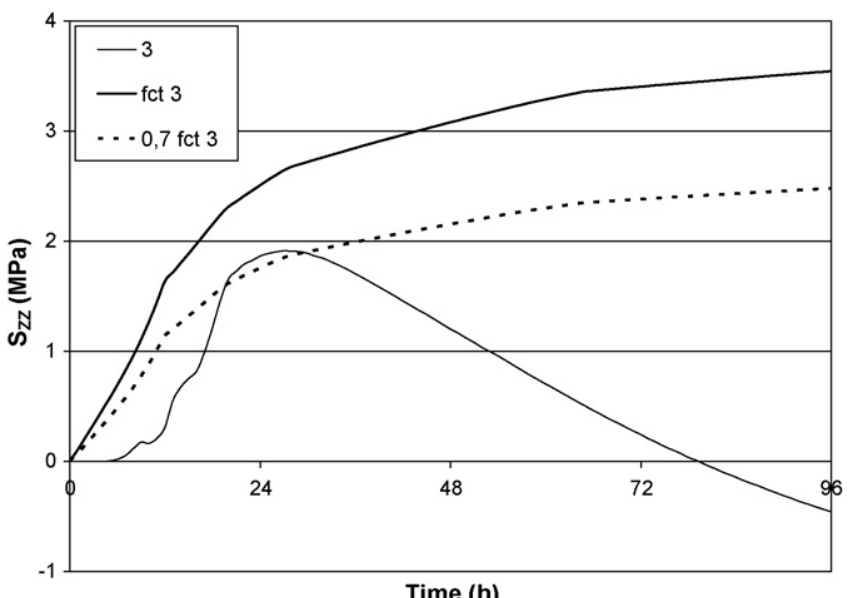

Fig. 20. Time graph of $S_{\mathrm{zz}}$ development for SCC at point 3 , casting temperature $30^{\circ} \mathrm{C}$, environmental temperature $30^{\circ} \mathrm{C}$.
In order to describe the age-dependent physical and mechanical processes, a maturity-based model has been implemented. The maturity $M$ is defined as:

$M(t)=\int_{t_{\text {con }}}^{t} e^{(Q / R)\left(\left(1 /\left(T_{\text {ref }}+273\right)\right)-(1 /(T+273))\right)} \mathrm{dt}$

$t$ is the actual time, $t_{\text {con }}$ is the casting time, $Q$ is the activation energy, $R$ is the universal gas constant, $T_{\text {ref }}$ is a reference temperature, and $T$ is the temperature. This is also known as the Arrhenius expression to take into account the influence of temperature history on the maturity. Properties such as tensile strength, compressive strength modulus of elasticity, creep, and shrinkage are maturity related.

The heat source is implemented by means of the adiabatical evolution of the hardening concrete and according to De Schutter and Taerwe (1996).

The visco-elastic material behaviour of mass concrete is described by means of a Maxwell model (Fig. 12) (Bazant, 1986), with $E_{k}$ the spring stiffness and $\tau_{k}$ the retardation time of branch $k$. These material properties are also dependent on the maturity.

For a more detailed discussion on the HEAT engineering tool and the used material models, reference is made to the literature (Van Beek et al., 2001; De Schutter and Vuylsteke, 2004).

\section{Geometry and boundary conditions}

The geometry of the construction is implemented into HEAT by defining three macro-elements. An axisymmetrical cross-section of the supercontainer has been made and will be applied as the two-dimensional model (Fig. 13).

The initial temperature of the macro-elements is set at $20^{\circ} \mathrm{C}$ and the environmental temperature will be kept at a constant value of $20^{\circ} \mathrm{C}$. The inside formwork, with a thickness of $10 \mathrm{~mm}$, is removed after $48 \mathrm{~h}$. The outside steel liner (thickness $=6 \mathrm{~mm}$ ), considering it will be used, on the other hand will not be removed at all.

The wind speed has a velocity of $1 \mathrm{~m} / \mathrm{s}$, but will be held out of consideration at the inside of the container. Before releasing of the internal formwork, the convection coefficient is $5.59 \mathrm{~W} /\left(\mathrm{m}^{2} \mathrm{~K}\right)$ and after releasing the formwork its value is $5.6 \mathrm{~W} /\left(\mathrm{m}^{2} \mathrm{~K}\right)$. The steel formwork provides almost no insulation. The convection coefficient is $9.6 \mathrm{~W} /\left(\mathrm{m}^{2} \mathrm{~K}\right)$ on top of the container (free surface) and $2.0 \mathrm{~W} /\left(\mathrm{m}^{2} \mathrm{~K}\right)$ at the bottom (massive concrete floor). HEAT has a tool that calculates the convection coefficient depending on the material type, thickness, wind speed and coverage.

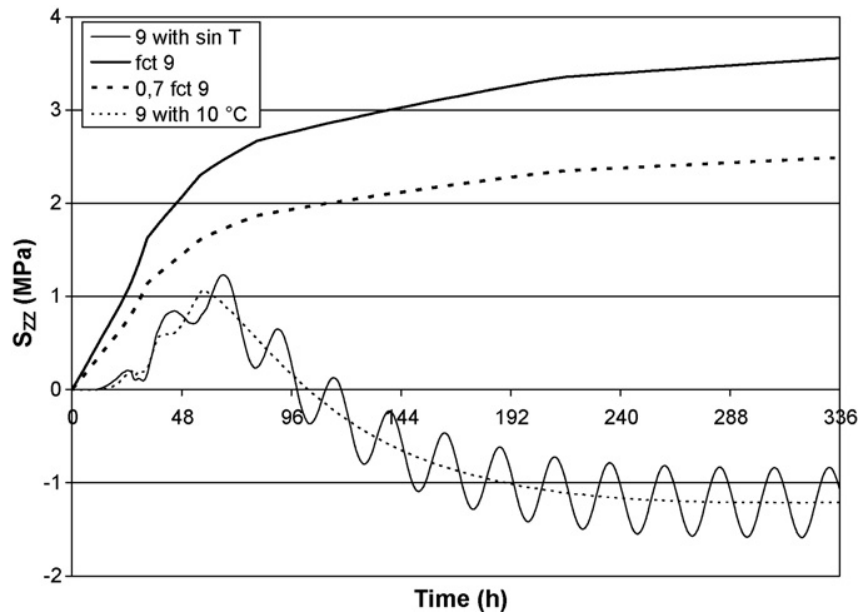

Fig. 21. Time graph of $S_{z z}$ development for SCC at point 9, casting temperature $10^{\circ} \mathrm{C}$ realistic environmental temperature (sine curve). 


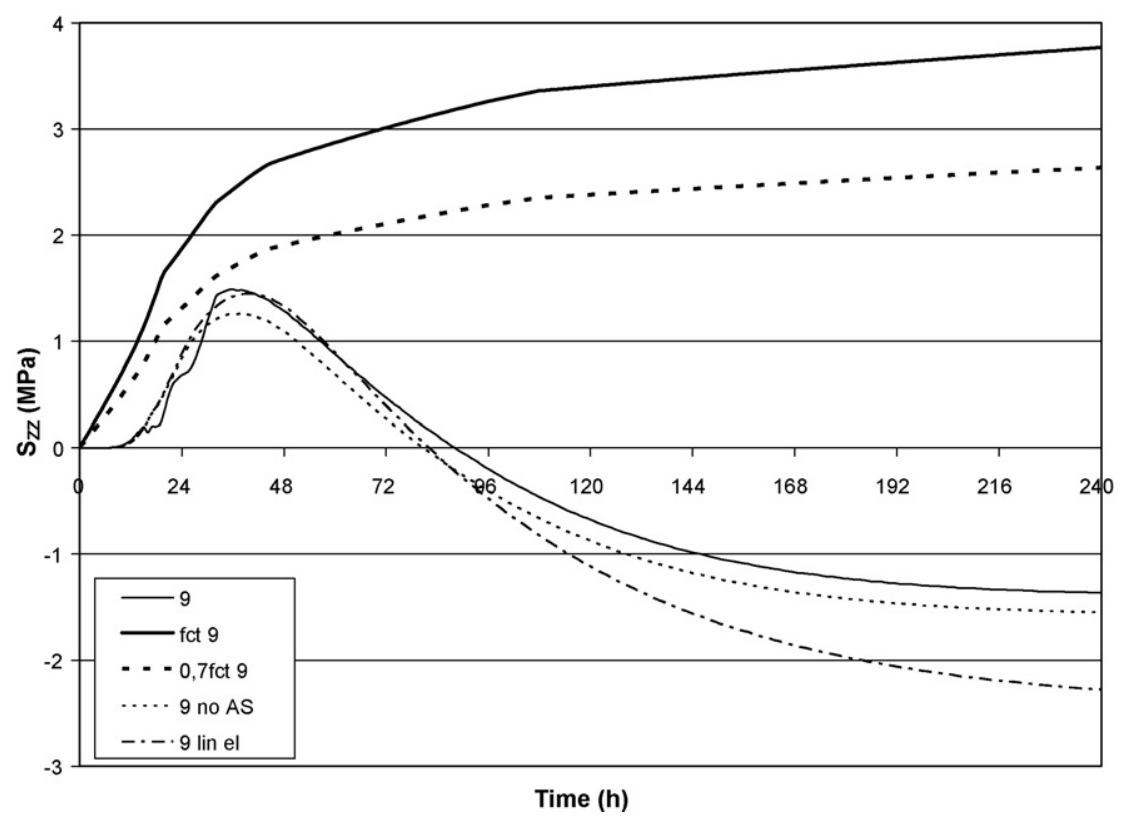

Fig. 22. Time graph of $S_{z z}$ development for SCC at point 9 , casting temperature $20^{\circ} \mathrm{C}$, environmental temperature $20^{\circ} \mathrm{C}$.

The container is simply supported by the concrete border (kinematic boundary condition).

For the simulation of the second stage of manufacturing of the supercontainer, the insertion of the heat-emitting canister after $240 \mathrm{~h}$, the same boundary conditions are used until the time of emplacement. Afterwards, at the outer surface, there is a maintenance of the temperature, wind velocity, thus the convection coefficient. On the other hand, a heat source is placed inside the concrete buffer, at the inner surface. Assuming a limestone filler is being used directly after the canister is placed, according to stage 3 of manufacturing of the supercontainer, the convection coefficient at the inner surface is $4.4 \mathrm{~W} /\left(\mathrm{m}^{2} \mathrm{~K}\right)$. The temperature is $20^{\circ} \mathrm{C}$ at the inner surface until $240 \mathrm{~h}$, and then rises uniformly to a value of $63.1^{\circ} \mathrm{C}$ after $1344 \mathrm{~h}$ (Fig. 14) (Poyet, 2007).

The macro-layers are divided into elements, yielding the mesh given in Fig. 15. Towards the edges of the supercontainer, the size of the elements is reduced.

\section{Post-processing}

\subsection{First simulation: $20^{\circ} \mathrm{C}$}

In a first simulation, the casting temperature of the concrete and the outside temperature are equal to $20^{\circ} \mathrm{C}$. When we look at the contourplots of the temperature we assess that the highest temperature occurs inside the core of the bottom of the concrete buffer (Fig. 16). For SCC the maximum temperature is $54.24^{\circ} \mathrm{C}$ at $41 \mathrm{~h}$. The temperature peak of TVC is slightly lower $\left(52.76^{\circ} \mathrm{C}\right)$ and occurs $4 \mathrm{~h}$ earlier (at $37 \mathrm{~h}$ ).

The most significant question however is whether the tensile stresses, due to the developed thermal gradients, the autogenous shrinkage of the concrete, and taking into account the creep effect, will exceed the tensile strength of the concrete buffer, giving cause to early age cracking. The results show that early age cracking of the buffer will not occur. At all times, the radial $\left(S_{x x}\right)$, axial $\left(S_{y y}\right)$ and tangential $\left(S_{\mathrm{zz}}\right)$ stresses remain smaller than $0.7 f_{\mathrm{ct}}$. According
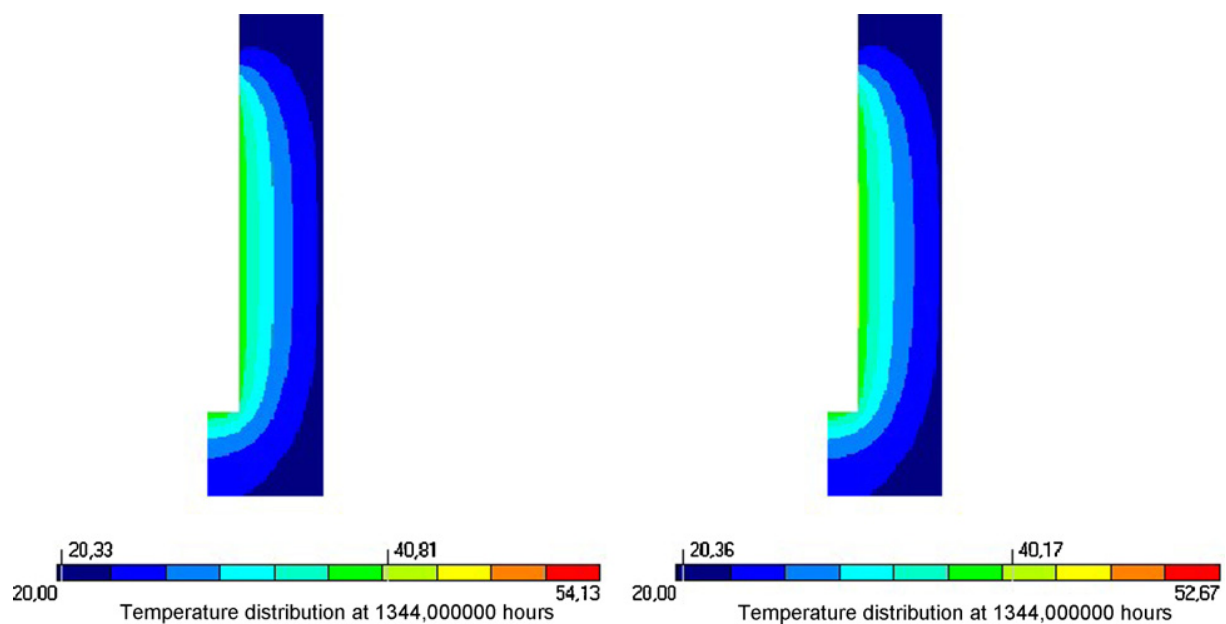

Fig. 23. Contourplot of the temperature after $1344 \mathrm{~h}$ (left: SCC, right: TVC), casting temperature $20^{\circ} \mathrm{C}$, environmental temperature $20^{\circ} \mathrm{C}$, insertion of canister after 240 h. 
to Reinhardt and Cornelissen (1985) $f_{\mathrm{ct}, \infty}$ equals 0.7 times $f_{\mathrm{ct}, 0}$ due to the long term effect of tensile strength, therefore the factor 0.7 is used as a safety limit. Furthermore, the tensile stresses (mainly due to hydration heat) inside the SCC are slightly higher than inside the TVC. The region with the highest tensile stress build up is located near the outer surface of the buffer (Fig. 17). The stress-strength ratio $S_{\mathrm{zz}} / 0.7 f_{\mathrm{ct}}$ is also higher for SCC in comparison to TVC. Near the outer surface, this ratio has a value of approximately 0.9 for SCC and 0.7 for SCC (Fig. 18). During the cooling period there are regions inside the buffer that may experience tensile stresses (point 4 ). These stresses, in the middle of the buffer are much lower than the tensile stresses near the outer surface during heating (Fig. 18). It must be noticed that the tensile stresses in the middle of the buffer during the cooling period are higher for TVC. On the other hand, cracking due to cooling of the buffer is not expected.

\subsection{Influence of temperature}

If we change the casting temperature of the concrete and the outside temperature to a value of $10^{\circ} \mathrm{C}$, we notice that the temperature peak is lower (about $15^{\circ} \mathrm{C}$ difference) than in the case of $20^{\circ} \mathrm{C}$ and occurs about $12 \mathrm{~h}$ later (Fig. 19). The developed stresses generate no early age cracking danger.

In case of a temperature increase, up to $30^{\circ} \mathrm{C}$, the temperature peak occurs $10 \mathrm{~h}$ earlier and is about $15^{\circ} \mathrm{C}$ higher than in the case of $20^{\circ} \mathrm{C}$. The axial and the tangential stresses become slightly higher than the $0.7 f_{\mathrm{ct}}$ limit (Fig. 20). To prevent early age cracking, practical measures have to be considered in this case.

In a last simulation, a more realistic environmental temperature condition is being considered, with daily cycle between $13.5^{\circ} \mathrm{C}$ and $6.5^{\circ} \mathrm{C}$ (mean value of $10^{\circ} \mathrm{C}$ ). The time-dependent stress development is shown in Fig. 21. No early age cracking behaviour is expected in this.

\subsection{Influence of shrinkage and creep effects}

As a final scope, we simulate the behaviour of the concrete buffer, first by leaving the autogenous shrinkage aside, and sec- ond by looking at the buffer as a linear elastic element (creep effect and autogenous shrinkage is not being considered). Tension is taken positive.

Looking at the linear elastic behaviour at point 9 (Fig. 22), we notice a tension build up the first hour after casting, with a maximum occurring at approximately $40 \mathrm{~h}$ due to the heat of hydration. Afterwards, due to the cooling of the element, the concrete at point 9 is coming under compression, which explains the stress drop. Taking into account the creep effect, we see that this stress drop becomes smaller and a stress of $-1.55 \mathrm{MPa}$ after $336 \mathrm{~h}$ is noticed instead of $-2.28 \mathrm{MPa}$ in the linear elastic case. The peak due to the heat of hydration also becomes smaller. Finally, by introducing the autogenous shrinkage behaviour into the simulation model, the stress peak due to the heat of hydration is bigger and occurs $4 \mathrm{~h}$ earlier later then the linear elastic case. The stress introduced into the concrete (cooling phase) reaches a value of about $-1.36 \mathrm{MPa}$ after $336 \mathrm{~h}$.

Note that the transient thermal creep has not been taken into account in this study. Numerical simulations performed by Benboudjema and Torrenti (2008) on a concrete containment show however that the effect of transient thermal creep is important for massive structures.

\subsection{Stage 2: insertion of the heat-emitting canister}

After the concrete buffer has been casted, the heat-emitting high level waste must be placed inside the buffer (in hot cell). In this simulation, the emplacement occurs $240 \mathrm{~h}$ after the casting of the concrete buffer. Looking at the contourplots of the temperature we notice that the maximum temperature at the inner surface after $1344 \mathrm{~h}$ (end of simulation) is $40.81^{\circ} \mathrm{C}$ for SCC and $40.17^{\circ} \mathrm{C}$ for TVC (Fig. 23).

The stress-strength ratio $S_{\mathrm{zz}} / 0.7 f_{\mathrm{ct}}$ indicates that the stress development inside the buffer (point 4) during the cooling is being reduced due to the insertion of a heat source (Fig. 24). Near the outer surface (point 9), there is a build up of tensile stresses due to the heating of the canister, but these tensile stresses are counteracted by the compressive stress build up due to the cooling

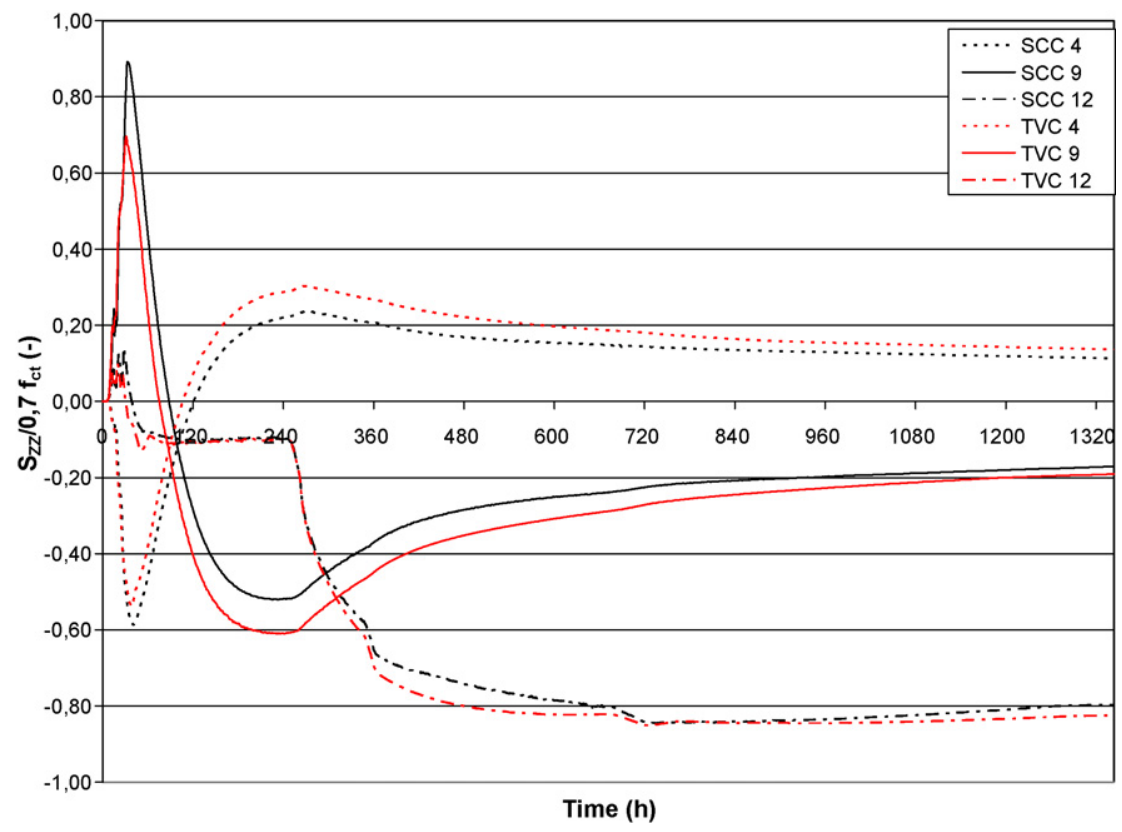

Fig. 24. Time graph of the stress-strength ratio $S_{\mathrm{zz}} / 0.7 f_{\mathrm{ct}}$ for SCC and TVC at points 9,4 and 12 . 
phase at stage 1 . Finally, at the inner surface (point 12) there is a major compressive stress build up: the concrete at the inner surface wants to expand more than the concrete inside the buffer. TVC in comparison with SCC has higher tensile and compressive stresses, but stress-strength ratio $S_{\mathrm{zz}} / 0.7 f_{\mathrm{ct}}$ remains smaller than one at all times. Cracking in stage 2 due to heating of the buffer is not expected.

\section{Conclusions}

Massive hardening concrete elements are very prone to early age thermal cracking due to the heat of hydration and the autogenous shrinkage. Finite element simulations are performed for the first production step of the supercontainer, where the concrete buffer is cast into the outer steel liner, in order to investigate the problem of early age cracking. Long term creep test and shrinkage test are performed to predict the behaviour of the concrete buffer. These mechanical properties are implemented into the material database of the simulation tool HEAT. From the simulations, the following conclusions can be obtained:

- If the environmental temperature does not exceed a value of $20^{\circ} \mathrm{C}$, no early age cracking is expected in stage 1 . The axial, radial and tangential stresses remain, at all times, smaller than $0.7 f_{\text {ct. The }}$ insertion of a heat-emitting source inside the buffer also does not create additional cracking.

- The temperature development, due to the hydration heat, is smaller in case of the traditional concrete (TVC) in comparison with self-compacting concrete (SCC).

- Measures have to be taken in case of an environmental temperature of $30^{\circ} \mathrm{C}$, in order to avoid thermal cracking.

- Creep and autogenous shrinkage have a non-negligible effect on the simulation results.

- SCC experiences a bigger creep effect and larger shrinkage than RPC.

\section{References}

Bel, J., Van Cotthem, A., De Bock, C., 2005. Construction, operation and closure of the Belgian repository for long-lived radioactive waste. In: Proceedings of the 10th International Conference on Environmental Remediation and Radioactive Waste Management, Glasgow, Scotland.

Bazant, Z.P., 1986. Creep and shrinkage of concrete. Mathematical modelling. In: Proceedings of the Fourth RILEM International Symposium on Creep and Shrinkage of Concrete, Evanston.

Benboudjema, F., Torrenti, J.M., 2008. Early age behaviour of concrete nuclear containements. Nuclear Engineering and Design, doi:10.1016/j.nucengdes. 2008.04.009.

Craeye, B., De Schutter, G., 2006. Experimental evaluation of mitigation of autogenous shrinkage by means of a vertical dilatometer for concrete. In: Proceedings of the International RILEM Conference on Early Age Shrinkage Induced Stresses, Copenhagen, Denmark.

Craeye, B., De Schutter, G., Bel, J., Van Humbeeck, H., Van Cotthem, A. 2007. Development of a SCC composition for disposal of heat-emitting, radioactive waste in Belgium. In: Proceedings of the 5th International RILEM Symposium on Selfcompacting Concrete, Ghent, Belgium.

CUR report 172,2004 . Durability and maintenance of concrete structures, pp. $106-115$ (in Dutch).

De Schutter, G., 2002. Finite element simulation of thermal cracking in massive hardening concrete elements using degree of hydration based material laws. Computers \& Structures 80, 2035-2042.

De Schutter, G., Bartos, P., Domone, P., Gibbs, J., 2008. Self Compacting Concrete. Whittles Publishing, Caithness, UK, p. 296.

De Schutter, G., Taerwe, L., 1996. Fundamental and practical study of thermal stress in hardening massive concrete elements. Doctoral Thesis, Ghent, Belgium (in Dutch).

De Schutter, G., Vuylsteke, M., 2004. Minimisation of early age thermal cracking in J-shaped non-reinforced massive concrete quay wall. Engineering Structures 26 , 801-808.

ONDRAF/NIRAS, 2004. A review of corrosion and material selection issues pertinent to underground disposal of highly active nuclear waste in Belgium, Report 200402.

Poppe, A.M., De Schutter, G., 2004. Influence of fillers on the hydration and other properties of self compacting concrete. Doctoral Thesis, Ghent, Belgium (in Dutch).

Poyet, S., 2007. Design of the ONDRAF supercontainer concept for vitrified HLW disposal in Belgium: study of the thermo-hydrological behaviour of the buffer. Rapport CEA RT DPC/SCCME/07-741-7.

Reinhardt, H.W., Cornelissen, H.A.W., 1985. Zeitstandzugversuche an Beton. Baustoffe 85, Bauverslag, Wiesbaden, pp. 162-167.

Van Beek, A., Schlangen, E., Baetens, B.E.J. 2001. Numerical model for prediction of cracks in concrete structures. In: Proceedings of the International RILEM Conference on Early Age Cracking in Cementious Systems, EAC'01, Haifa, Israel. 